Vol. 1

October 2000

pp. $15-36$

\title{
CPA Attested Tax Returns and Tax Evasion*
}

\begin{abstract}
Suming $\operatorname{Lin}^{* *}$
ABSTRACT: For a considerable number of years, business income tax returns attested by a certified public accountant (CPA) have enjoyed special tax incentives. There has, however, been no documentary evidence to justify the existing tax incentive policy. This study, which uses a Tobit model to undertake an analysis of business income tax return data, empirically demonstrates that CPA attested tax returns are more compliant with the tax law than non-attested tax returns. This finding suggests that tax authorities should continue to promote the use of CPA attested tax returns. As well, this finding recommends the auditing of a greater proportion of non-attested returns in order to reduce the incidence of tax evasion.
\end{abstract}

Key Words: Attested tax returns, Tax evasion, CPA, Tobit model, Tax policy.

Data Availability: from the Data Processing Center, Ministry of Finance; data available for academic research with permission.

\section{INTRODUCTION}

In an effort to reduce the workload of the tax authorities in Taiwan, and to assist firms in meeting their tax obligations, Article 102 of the Income Tax Law prescribes that a firm may entrust a certified public accountant (CPA) to prepare, attest and file its business income tax returns. In preparing an attested tax return, the entrusted CPA is responsible for checking the firm's accounting records and related documentary evidence, adjusting the accounting income to taxable income based on the tax law, and attaching a signed 'tax return attestation report' to the tax return. In cases where an attested return is selected as part of an auditing sample, tax officials generally conduct the audit based on the tax return attestation report. Only when certain abnormalities are found will the tax

\footnotetext{
* This paper has benefited from the comments of two anonymous reviewers, as well as Chih-Chung Yeh, Tsing-Zai Wu, William W. Sheng, Chung-Yuan Hsi, Po-Kuei Chen and participants in workshops at National Cheng Kung University, and the Fourth Taiwan Conference on Accounting Research, cosponsored by the Taiwan Accounting Association and Tunghai University, which awarded the Best Empirical Paper prize to an earlier version of this paper (in Chinese). The author is grateful to Yu-Ming Yang, Director General of the Data Processing Center, Ministry of Finance, for data used in this study. This research was funded by the National Science Council.

** Suming Lin is an Associate Professor at the National Taiwan University; e-mail: suming @ mba.ntu.edu.tw
} 
officials normally demand to examine the CPA's attestation worksheet and the firm's accounting records.

For those firms whose tax returns are attested by a CPA, the Income Tax Law provides various tax incentives, including additional deductibility of entertainment expenses, the carry forward of net losses, and an extension of filing deadline. Thus far, however, no evidence has been documented to justify the policy of offering such tax benefits to those firms opting for CPA attested tax returns. The purpose of this study, therefore, is to empirically examine incidences of tax evasion among CPA attested business income tax returns versus ordinary (non-attested) returns, as a means of investigating the effectiveness of the tax return attestation system. In other words, if empirical results indicate a wider prevalence of tax evasion among CPA attested tax returns than among ordinary tax returns, then the aim of the attestation system - i.e., to reduce the workload of tax authorities and assist firms in meeting their tax obligations will not have been effectively met. The findings of this study will, therefore, provide certain policy implications as to whether the government should curtail, or indeed extend, the scope of the tax return attestation system. As well, they will give guidance as to whether there should be any expansion or reduction in the auditing budget of tax authorities with respect to CPA attested tax returns.

While there are certain specific firms that are required by the tax law to use CPA attested tax returns, other firms can also elect to use CPA attested returns and thus enjoy those tax advantages made available as a means of encouraging tax attestation. Nevertheless, even with these incentives, the attestation system is still not widely employed by firms. For instance, CPA attested returns accounted for just $8.2 \%$ of all tax returns reported for 1994, a ratio of approximately 12:1 in favor of non-attested returns (see Table 1). In accordance with the administrative regulations prescribed by the Ministry of Finance, all listed companies, financial and insurance institutions and firms with annual net sales of NT $\$ 100$ million or more must entrust their tax returns to CPAs for attestation. However, ironically, no penalties exist for those who ignore this requirement since no authorization has been provided by the Legislative Yuan (Taiwan's congress) to the Ministry of Finance to stipulate such penalties. As a result, some firms may well be encouraged to evade their tax liability by disregarding the attestation requirement. ${ }^{1}$

Another important reason for the current limited use of attested tax returns is the Expanded Paper Review (EPR) system. The EPR system can be used by firms whose total amount (total receipts) of net operating revenue and gross non-operating revenue (excluding transaction gains from lands, adhered properties of lands and tax exempt income) is NT $\$ 30$ million or less. Irrespective of the gains or losses that a firm has actually made, once the firm's reported net profit ratio reaches the prescribed industry profit standard, and full tax payment is made, the EPR system will assess the firm's income tax in light of the information available on the 'papers' presented with the tax returns. ${ }^{2}$ On the one hand, a firm with net losses may willingly pay tax under the EPR

\footnotetext{
${ }^{1}$ As Table 2 indicates, about 4,380 firms with net sales over NT $\$ 100$ million did not use a CPA to attest their 1994 tax returns.

${ }^{2}$ Under the EPR system, a firm's taxable income is generally calculated by multiplying its sales revenue by the prescribed industry profit standard (generally around 6\%), regardless of the gain or loss that the firm
} 
system in order to dispose of the time-consuming process, and perhaps even psychological anxiety, caused by dealing with tax officials; on the other hand, however, a firm which conceals a proportion of its sales receipts through its intentional failure to issue uniform invoices, can take advantage of the EPR system to pay a much lower level of tax than the amount which would be assessed through auditing its accounting records and related documents.

If the evidence suggests a greater level of compliance with the tax law among CPA attested tax returns than ordinary tax returns, then tax return attestation clearly does achieve the goal of reducing the workload of tax authorities. Accordingly, it would then be advisable for the Ministry of Finance to expand the tax return attestation system, for example, to firms with net sales over NT $\$ 80$ million, as opposed to the current standard of NT\$100 million. It would also seem sensible for the Ministry of Finance to narrow the scope of the EPR system, for example, to firms with total receipts of less than NT\$20 million, from the current NT\$30 million. ${ }^{3}$ It also seems reasonable for the Legislative Yuan to propose an early amendment to the Income Tax Law to allow for the imposition of penalties against those firms whose tax returns are not attested by a CPA in disregard of the tax regulations. The empirical results of this paper may, therefore, offer some relevant evidence and guidance in the formulation of tax policy in the Ministry of Finance and the Legislative Yuan.

The remainder of this paper proceeds as follows. Section 2 briefly reviews the existing work on tax evasion and the attestation of Taiwanese companies' tax returns. The methodology adopted for this study is introduced in Section 3, along with the data source of the study. The empirical results are presented in detail in Section 4, with Section 5 offering concluding remarks.

\section{LITERATURE REVIEW}

Ever since the 1970s, tax evasion has attracted considerable attention on a worldwide scale among academic researchers and tax policy makers. More recently, some of this attention has begun to focus upon the effect on tax evasion behavior of the tax services provided by CPAs. This section briefly reviews the previous work on tax evasion related topics.

Allingham and Sandmo (1972) presented one of the earliest and most famous theoretical studies on tax evasion. Their model, a straightforward application of individual choice under expected utility theory, aimed to determine the effect on tax evasion of government instruments, such as changes in the penalty for evasion, audit probability and tax rates. Among the main findings, it was noted that under-reported income drops as the government increases the penalty rate or the probability of audit. However, their theoretical analysis failed to determine the emergence of any clear-cut relationship between tax rate and reported income.

As a pioneering example of the empirical study of tax evasion, the work of

actually has. The sales revenue is decided according to the total amount shown on the uniform invoices issued by the firm. All of the uniform invoices throughout Taiwan must be pre-numbered and consequently controlled by the Ministry of Finance.

3 A firm whose total receipts exceed NT\$20 million is then deprived of using the EPR system, and it may decide to opt for tax return attestation. 
Clotfelter (1983) used 1969 data from the US Internal Revenue Service's Taxpayer Compliance Measurement Program (TCMP) to investigate the relationship between marginal tax rate and individual income tax evasion, with the difference between assessed and reported income being used as a proxy for evasion. One of the most important empirical findings was that marginal tax rate had a significantly positive association with tax evasion. Since there was no evidence of evasion in a sizable proportion of the observations, the dependent variable was censored at zero, and Clotfelter, therefore, adopted Tobit regression analysis. This paper, like Clotfelter's, will employ the Tobit model for statistical analysis.

Based on the prospect theory of Kahneman and Tversky (1979), Chang and Schultz (1990) proposed that differential tax compliance exists between taxpayers with additional tax due (under-withheld) at filing time, and taxpayers who are due to receive tax refunds (over-withheld). Using the 1982 TCMP data, they provided evidence consistent with their proposition. More recently, Yaniv (1999) also applied the prospect theory to a theoretical model to mathematically demonstrate that advance tax payments will affect the decision to evade tax. Following on from Chang and Schultz (1990), the present study will examine whether a firm's refund-due or balance-due position at filing time has an impact on business income tax evasion.

Beck et al. (1991) utilized an experimental design to explore the under-reported income of taxpayers under different tax rates, penalty rates, and audit probabilities, and under different levels of income uncertainty. Among their findings, they reported that tax compliance rises with penalty rate and audit probability, but that there is no identifiable relationship with the taxpayer's tax rate. Risk averse taxpayers will be more compliant when the uncertainty of income is increased (i.e., when the tax law becomes more ambiguous).

Turning to the studies on the impact of the role of CPAs on tax evasion, Klepper et al. (1991) argued that since tax professionals (e.g., CPAs and lawyers in the US) are subject to disciplinary sanctions for willful or negligent breach of tax rules, they will undoubtedly help to enforce the clear requirements of the tax law. However, since tax professionals are also more astute and knowledgeable than the general public in terms of finding ways to exploit the tax law, they will also help taxpayers take advantage of any ambiguous provisions of the law. Klepper et al. (1991), therefore, present a theoretical model, which jointly addresses the decision to engage a tax professional and the tax evasion outcomes conditional on whether a professional is engaged. However, only the latter is empirically tested. The 1982 TCMP data is used in the test, and ambiguity is measured using the number of revenue rulings pertaining to the line item, divided by the true amount of that line item. The test results were basically as they had predicted; that is, where ambiguous line items are involved, tax professionals will play an advocacy role, thus contributing to greater evasion, whereas, in the case of unambiguous line items, such professionals will play an enforcement role, contributing to greater compliance. Survey studies also present similar results. In an experiment using the partners and managers of the (then) Big 6 CPA firms as subjects, Spilker et al. (1999) provided evidence to show that tax professionals will interpret ambiguity to the benefit of their clients in a compliance decision context. Based on the 1982 TCMP data, Erard (1993) also found that returns prepared by tax professionals were more aggressive in tax evasion than returns 
prepared by taxpayers themselves. However, in contrast to Klepper et al. (1991) and Erard (1993), who examined personal income tax evasion, this paper concentrates on business income tax.

There have also been some studies investigating tax evasion, or a CPA's tax services, in Taiwan. Huang (1982) compared personal income in the national income accounts, and the income reported in all of the individual income tax returns, concluding that around $71 \%$ of income was unreported by taxpayers in the 1979 tax year. Again based on national income accounts, Chen (1987) found that around 53\% of business income was unreported in 1983 business income tax returns. The proportion of under-reported income was also found to vary among different industries in Taiwan.

Chu (1988) interviewed 54 of Taiwan's CPAs in an attempt to establish the possible factors that cause businesses to evade tax. According to his MIMIC (multiple-indicator-multiple-cause) analysis, significant indicators of business income tax evasion include the quality and integrity of tax officials, the tax rate structure, and the flexible interpretation of the tax law. However, the role played by a CPA in tax evasion was beyond the scope of his research.

Wang et al. (1993) conducted a questionnaire survey and held panel discussions to examine the benefits of using CPA attested tax returns. Their main findings, as they relate to this paper were: (i) the reasons for using CPA tax attestation included 'a good bargain to entrust tax attestation along with financial attestation', 'can enjoy tax preferences', 'required by tax regulations', etc.; (ii) approximately $66 \%$ of CPA attested tax returns were selected for subsequent tax audit, while $57 \%$ of ordinary returns were selected; and (iii) in the opinion of tax officials and businesses, CPA tax attestation has played a positive role - CPAs can assist firms to fulfill their tax obligations and simultaneously safeguard the firms' interests. In addition, tax attestation reduces tax authorities' audit workload and costs.

While the Wang et al. (1993) study utilized a survey approach; the present study will employ micro-unit data from real tax returns to investigate any specific association between CPA tax attestation and business income tax evasion.

\section{METHODOLOGY}

\section{Data and Sample}

Business income tax returns filed for the tax year 1994 are used as the data for this study. The Data Processing Center of the Ministry of Finance maintains an annual record, on computer disks, of reported amounts of all items on original tax returns, and the amounts deemed 'correct' following audit by tax authorities. ${ }^{4}$

The filing modes of all business income tax returns reported for the 1994 tax year are shown in Table 1, revealing that around half a million returns were filed in Taiwan during that year, and that most returns, around 63.4\%, used the Expanded Paper Review (EPR) system. Those firms with total operating and non-operating receipts not exceeding NT\$30 million, which could opt to use the EPR system, but chose not to, accounted for

\footnotetext{
${ }^{4} 1994$ tax year returns were filed in 1995. It takes around two years to audit these returns and to store the data on computer disks. Therefore, by using the 1994 tax year data, this study obtained the latest available data, to February 1998, when the study commenced.
} 
$18.8 \%$ of the total returns. The combination of these two groups indicates that more than $80 \%$ of all returns came from businesses with total receipts not exceeding NT $\$ 30$ million. Only around 45,000 firms, less than $10 \%$ of the total, entrusted their tax returns to CPA attestation.

The sample for statistical analysis excludes firms with total receipts not exceeding NT\$30 million, since they have the option of applying the EPR system and records in the EPR returns are often incomplete. Firms whose net sales were equal to, or greater than, NT $\$ 100$ million are also eliminated from the sample because they are compelled to use CPA attested tax returns under current tax regulations.

Table 2 demonstrates the sample selection procedure. The numbers displayed in the second row are taken from Table 1, and after eliminating the firms with total receipts not exceeding NT $\$ 30$ million and those firms with net sales of NT\$100 million and above, we are left with 14,998 CPA attested tax returns, and 22,321 ordinary returns.

Table 1 Filing modes for business income tax returns reported for the 1994 tax year

\begin{tabular}{|c|c|c|}
\hline Filing Modes & Total & Percentage \\
\hline CPA-attested tax returns & 44,998 & 8.2 \\
\hline EPR returns (total receipts $\leqq N T \$ 30$ million) ${ }^{1}$ & 346,581 & 63.4 \\
\hline Ordinary returns (total receipts $\leqq N T \$ 30$ million) & 102,882 & 18.8 \\
\hline Ordinary returns (total receipts $>$ NT $\$ 30$ million) & 26,701 & 4.9 \\
\hline Others $^{2}$ & 25,617 & 4.7 \\
\hline Total & 546,779 & 100.0 \\
\hline
\end{tabular}

Notes:

1.For an explanation of EPR (Expanded Paper Review) returns, please see the Introduction section.

2. Including returns of educational, cultural, public welfare, or charitable organizations, returns of foreign corporation branches in Taiwan, returns of government-controlled firms, returns of firms changing their fiscal year, returns of liquidating firms, etc.

Firms that did not report balance sheet data, those for which tax assessed data after official audits were unavailable, or those that included missing or illogical values are further deleted from the sample. ${ }^{5}$ In the final stage, the sample consists of 34,356 observations, including 14,082 CPA attested tax returns (41\%) and 20,274 ordinary returns $(59 \%){ }^{6}$

Table 3 divides the CPA attested returns and ordinary returns selected in the sample into two groups, respectively; those firms within which tax evasion was subsequently found in an official audit (defined below), and those firms not found to have been involved in any tax evasion. Of those firms using ordinary returns, there were 11,548 that were found to have evaded taxes, far more than the 2,904 firms that had used CPA attested returns that were found to be evading taxes.

\footnotetext{
5 The Data Processing Center retains business income returns data in three files: Income Statements, Balance Sheets and Tax Assessed after Audits. These files can be merged according to each firm's 8-digit business identification number assigned by the government. Before the Data Processing Center releases the data for academic research, the identification number is transformed by a certain formula unknown to the public.

${ }^{6}$ There are 163 firms with reported tax liability greater than the assessed tax liability after audit. They are deemed as erroneous observations and deleted from the sample.
} 
Table 2 Sample selection procedure and number of sample observations

\begin{tabular}{|c|c|c|c|}
\hline Selection Procedure & $\begin{array}{r}\text { CPA-attested } \\
\text { Tax Returns }\end{array}$ & $\begin{array}{r}\text { Ordinary Returns } \\
\text { with Receipts } \geq \\
\text { NT } \$ 30 \text { million } \\
\end{array}$ & Total \\
\hline Firms reporting income statement in tax return & 44,998 & 26,701 & 71,699 \\
\hline $\begin{array}{l}\text { Less: receipts } \leqq N T \$ 30 \text { million } \\
\text { or net sales } \geqq N T \$ 100 \text { million }\end{array}$ & $-30,000$ & $-4,380$ & $-34,380$ \\
\hline $\begin{aligned} \text { Firms with receipts } & >\mathrm{NT} \$ 30 \text { million } \\
\text { and net sales } & <\mathrm{NT} \$ 100 \text { million }\end{aligned}$ & 14,998 & 22,321 & 37,319 \\
\hline $\begin{array}{l}\text { Less: firms without balance sheet or tax } \\
\text { assessed data after audit }\end{array}$ & -724 & $-1,666$ & $-2,390$ \\
\hline Subtotal & 14,274 & 20,655 & 34,929 \\
\hline Less: firms with missing or illogical values & -192 & -381 & -573 \\
\hline Total No. of observations used in the sample & 14,082 & 20,274 & 34,356 \\
\hline
\end{tabular}

Table 3 Occurrences of tax evasion in CPA attested and ordinary tax returns

\begin{tabular}{lrrrrrr}
\hline & \multicolumn{2}{c}{ CPA-attested returns } & \multicolumn{2}{c}{ Ordinary returns } & \multicolumn{2}{c}{ Total } \\
\cline { 2 - 7 } & No. of & $\begin{array}{r}\text { Average } \\
\text { Evasion } \\
\text { Firms }\end{array}$ & $\begin{array}{r}\text { No. of } \\
\text { Firms }\end{array}$ & $\begin{array}{r}\text { Average } \\
\text { Evasion } \\
(\text { NT\$) }\end{array}$ & $\begin{array}{r}\text { No. of } \\
\text { Firms }\end{array}$ & $\begin{array}{r}\text { Average } \\
\text { Evasion } \\
(\text { NT\$) }\end{array}$ \\
\hline $\begin{array}{l}\text { Firms with tax } \\
\text { evasion found }\end{array}$ & 2,904 & 171,721 & 11,548 & 266,285 & 14,452 & 247,283 \\
$\begin{array}{l}\text { Firms with no tax } \\
\text { evasion found }\end{array}$ & 11,178 & - & 8,726 & - & 19,904 & - \\
Total & 14,082 & 35,413 & 20,274 & 151,675 & 34,356 & 104,021 \\
\hline
\end{tabular}

In those firms within which tax evasion had been assessed, the average tax evasion from ordinary returns was NT $\$ 266,285$, far in excess of the average NT $\$ 171,721$ of the CPA attested returns, by around NT $\$ 95,000$ (the average reported tax liability was NT $\$ 189,000$ for ordinary returns, and NT $\$ 195,000$ for CPA attested returns).

\section{Variables}

Since all firms in the sample were restricted to total receipts in excess of NT\$30 million, and net sales of less than NT $\$ 100$ million, the amount of tax evasion is necessarily limited within a certain range. Therefore, the amount of tax evasion, as the dependent variable, will not be taken logarithmically or transformed into any other value. This will also ensure a much easier explanation of the statistical results. All the variables used in this study are listed in Table 4 below, followed by complementary explanations where necessary.

While under-reported income was used as the proxy of tax evasion by both Allingham and Sandmo (1972) and Clotfelter (1983), this study defines tax evasion as the amount of assessed additional tax, i.e., the tax liability that tax officials determined to be 
evasion of CPA attested returns differs from that of ordinary returns. As the extant literature has failed to provide a clear-cut theory capable of predicting the impact of CPA tax services on tax compliance, this study will try to investigate the association, rather than the causality, between the usage of CPA attested returns and tax evasion.

Based on Kahneman and Tversky's (1979) prospect theory, Chang and Schultz (1990) hypothesize that at filing time, individual taxpayers will assume their withholding position, i.e., whether under-withheld or over-withheld, as their reference point. Therefore, taxpayers with an under-withheld (tax balance due) position have a higher rate of tax evasion than taxpayers with an over-withheld (tax refund due) position. Simply because Chang and Schultz (1990) were able to present supporting evidence from US individual income tax data, the withholding position (the dummy variable PAY) will be used as an independent variable in this study.

A further independent variable, ETR (effective tax rate), is obtained by subtracting the applicable tax credits from the tax liability of the assessed taxable income, and then dividing this by the total assessed taxable and exempt income. When the denominator is less than or equal to zero, or when it is positive but the numerator is negative, the ETR is set at zero. Clotfelter (1983) found that US taxpayers with a higher marginal tax rate (MTR, rather than ETR), tended to have more income under-reported. Theoretically, MTR is more suitable than ETR as the explanatory variable of tax evasion; this is because, for a taxpayer to increase his under-reported income by $\$ 1$, his tax saving, if not detected by tax officials, will be the equivalent of MTR (\$MTR). However, where a firm's annual taxable income is over NT $\$ 100,000$, the applicable tax rate will be $25 \%$ (the highest in Taiwan). Since it is clear that the variation of firms' MTR will be quite small, this study uses ETR rather than MTR as an explanatory variable. Firms with more tax exempt income or more tax credits have a lower ETR, and these firms may well prove to be more compliant to the tax law because their tax burden is already low. Therefore, the conjecture is that ETR and tax evasion are positively related.

The more widespread the ownership, then the less the possibility that the benefits of business income tax evasion can be shared among a small number of people (for example, the management team). Tax return data maintained by the Data Processing Center, however, lacks information on the number of shareholders, or the proportion of shares held by the board of directors. Therefore, this study can only consider whether a firm is a limited corporation (limited by shares) as the proxy for the dispersion of ownership. If a firm is limited by shares then $\mathrm{ORG}=1$, otherwise $\mathrm{ORG}=0$ (e.g., for a partnership, a sole proprietorship, or a corporation in any other form).

A firm's financial position may impact upon its tax compliance behavior. A firm with a higher quick ratio (QUIC) has more funds available in the short term, therefore, it has less cash outflow pressure impacting upon income tax payment, and may, therefore, have a lower propensity to play the tax evasion game. Conversely, the higher a firm's debt ratio, the greater its interest expenses and bankruptcy risk and the lower its tax paying ability, thus, the higher will be its propensity to evade tax. In order to avoid any zeros arising in the denominator of the QUIC calculation, both the numerator and the denominator are increased by NT $\$ 10,000$, similar to the manipulation carried out in Broman (1989), and to avoid the extreme impact of the outliers, QUIC takes the quick ratio in natural logarithmic form. The debt ratio denoted by DEBT is total liability (plus 
NT $\$ 10,000$ ) divided by total assets (plus NT\$10,000), which then takes natural logarithm.

IRS1, .., IRS5 are the dummy variables for the tax office-in-charge. The Tobit model in the study has no constant term, so five dummies are taken to represent all five national tax administrations. In addition, all firms are classified into seven industry categories, according to the 6-digit industry code. (Refer to the notes in Table 4 for more information on industry codes).

A unique variable used in this study is RANK. Assume, for example, that a firm is under the jurisdiction of the National Tax Administration of the Southern Taiwan Province. This study ranks its net sales with every other firm in the same jurisdiction. If the firm ranks $R^{\text {th }}$ largest among the whole $S$ firms in that tax jurisdiction, then its RANK $=(1-\mathrm{R} / \mathrm{S}) \times 100$. It is speculated that a firm with larger RANK has a higher probability of selection for audit by the tax office-in-charge, and that the tax office will scrutinize its tax return more closely. Therefore, it is predicted that RANK will be positively associated with the amount of tax evasion detected by the tax office. The last column in Table 5 demonstrates the sample mean of each independent variable; this information is indispensable in the explanation of the results of Tobit analysis.

\section{Statistical Model}

As Table 3 indicated, there were 19,904 firms (about 58\% of the sample), which were not found to have evaded tax. Therefore, the dependent variable, i.e., the amount of tax evasion, was observed to be zero in a sizable proportion of the sample. Economists refer to this kind of data as 'censored data' (further clarification will follow). In his research on the household demand for durable goods, Tobin (1958) proposed a new statistical model to analyze his censored data. The model, designated as the Tobit model by Goldberger (1964), has been widely employed in social science research (Amemiya 1984), such as the Greene and Quester (1982) study of the working hours of female laborers, the Clotfelter (1983) examination of US tax evasion in individual income tax, and the Lin (1997) study of R\&D expenditure by Taiwanese manufacturers.

Similar to the argument in Tobin (1958), different firms may have different propensities towards tax evasion, even though they are not found to have evaded tax. Therefore, what we observe for the dependent variable $y_{i}$ (the evaded tax) is:

$$
y_{i}= \begin{cases}\beta x_{i}+\varepsilon_{i} & \text { if } y_{i}^{*}>0, \\ 0 & \text { otherwise, }\end{cases}
$$

where $y^{*}$ (the propensity to evade tax) is the latent variable, and:

$$
y_{i}^{*}=\beta x_{i}+\varepsilon_{i}, \quad i=1, \cdots, n, \quad \varepsilon_{i} \sim N\left(0, \sigma^{2}\right)
$$

If $y_{i}{ }^{*}>0$, the observed tax evasion is $y_{i}=y_{i}{ }^{*}$. If $y_{i}{ }^{*} \leqq 0$, only $y_{i}=0$ is observed, and the exact value of $y_{i}{ }^{*}$ is not observed. For example, even if firms $\mathrm{A}$ and $\mathrm{B}$ are both observed to have no tax evasion $\left(y_{A}=y_{B}=0\right)$, firm A may have a greater propensity towards evading tax $\left(y_{A}{ }^{*}>y_{B}{ }^{*}\right)$. Once business conditions are changed, $y_{A}{ }^{*}$ may exceed zero at greater speed than $y_{B}{ }^{*}$ so that $y_{A}>0$ will be observed while $y_{B}$ is still equal to zero.

Based on the explanations of the Tobit model in Greene (2000: Ch.20), Maddala (1983: Ch.6) and Judge et al. (1985: Ch.18), the following four equations derived from 
equations (1) and (2) are critical to this study:

$$
\begin{aligned}
& \mathrm{E}\left(y_{i} \mid x_{i}, y_{i}>0\right)=\beta^{\prime} x_{i}+\sigma \frac{\phi(z)}{\Phi(z)}, \\
& \frac{\partial \mathrm{E}\left(y_{i} \mid x_{i}, y_{i}>0\right)}{\partial x_{i j}}=\beta_{j}\left[1-z \frac{\phi(z)}{\Phi(z)}-\left(\frac{\phi(z)}{\Phi(z)}\right)^{2}\right], \\
& \mathrm{E}\left(y_{i} \mid x_{i}\right)=\beta^{\prime} x_{i} \Phi(z)+\sigma \phi(z), \\
& \frac{\partial \mathrm{E}\left(y_{i} \mid x_{i}\right)}{\partial x_{i j}}=\beta_{j} \Phi(z),
\end{aligned}
$$

where $\phi(\cdot)$ and $\Phi(\cdot)$ are notations for the standard normal density function and cumulative normal distribution function, respectively; $x_{i j}$ is the value of the $j^{\text {th }}$ variable in the $i^{\text {th }}$ observation vector (the $i^{\text {th }}$ firm); and $z=\beta^{\prime} x_{i} / \sigma$, the standard normal deviate.

Equation (3) is related to $y>0$ only. Given $x=x_{i}$, it is the expected value of tax evasion for those noncompliant firms $(y>0)$, while those firms with $y=0$ are excluded. As indicated in Judge et al. (1985:780), the traditional least squares regression will result in biased and inconsistent $\hat{\beta}$ (the estimator of $\beta$ ). This is because the second term in equation (3) is ignored. Given $x=x_{i}$, equation (4) represents the marginal effect of a unit increase in the $j^{\text {th }}$ variable of $x_{i j}$ vector on the expected value of $y_{i}$ for those tax evading firms only. Because this takes into account only the firms with $y>0$, it ignores the fact that the $x_{i j}$ change may cause some firms' propensity for evasion to increase from $y_{i}{ }^{*} \leqq 0$ to $y_{i}^{*}>0$, i.e., to become tax evaders from non-evaders.

On the other hand, equation (5) represents the overall expected value of tax evasion not only for the $y>0$ firms, but also for the $y=0$ firms. Equation (6) is the partial derivative function of equation (5), and this study will use equation (6) to predict the effect of a unit increase in the independent variable on the marginal increase in the tax evasion from both firms that already evaded tax, and those firms that had not been tax evaders but that would subsequently become evaders. Thus, Equation (6), rather than equation (4), plays the main role in this study because it carries more relevant tax implications.

The LIMDEP 7.0 software (Greene, 1995) is used for the maximum likelihood estimation of the Tobit model. As stated above, the partial derivative in equation (6) will be used to predict the marginal effect of independent variables. Although the marginal effects can be calculated for any pertinent values of the regressors, this study primarily calculates this at the means of the regressors $(\bar{x})$. However, for dummy variables (e.g., CPAD, PAY, and ORG) the partial derivative is not meaningful. Instead, taking CPAD as an example, we apply equation (5) to compute the marginal effect as follows, as was suggested in Greene (2000:817).

$$
\mathrm{E}\left(y_{i} \mid x=\overline{x_{i}} \text { except } C P A D=1\right)-\mathrm{E}\left(y_{i} \mid x=\overline{x_{i}} \text { except } C P A D=0\right)
$$

\section{EMPIRICAL RESULTS}

Table 5 summarizes the Tobit regression results, with the second column presenting the estimated $\beta$ coefficients, and the third column offering the $t$-statistics. Unlike cases in the linear model, the $\beta$ coefficients of the Tobit model, which is nonlinear, are not the 
marginal effects of independent variables on the dependent variable. According to equation (6), the marginal effects for continuous regressors are the $\beta$ coefficients multiplied by $\Phi\left(\beta^{\prime} \bar{x} / \sigma\right)$, and these are shown in the fourth column of Table 5 . However, the marginal effects of the dummy variables (CPAD, PAY, and ORG) are computed by equation (7). The last column provides the sample means of the independent variables. The means and the $\sigma$ value of equation (2) shown in Note 2 of Table 5 are indispensable to the computation of values in columns four and five. Taking IRS1 as an example, the $\mathrm{E}(y \mid \bar{x})=106,812$ in the second last column represents that for all sampled firms under the jurisdiction of the National Tax Administration of Taipei (IRS=1,IRS2 $=\cdots=$ IRS5=0), the average amount of tax evasion estimated at the means of all regressors, with the exception of tax jurisdiction dummies, is NT $\$ 106,812$.

The most important objective of this study was to undertake a comparison of business income tax evasion between CPA attested tax returns and ordinary returns. The Tobit analysis shows that the $\beta$ coefficient of CPAD is negative and statistically significant at the 0.01 level. The fourth column of Table 5, also demonstrates that the marginal effect of CPAD is -NT\$110,081; that is, setting all the independent variables except CPAD at their mean values, using these conditions as the base point for comparison, then on average, CPA attested tax returns under these conditions evaded less tax by about NT $\$ 110,000$ than ordinary tax returns under the same conditions. Therefore, the empirical results provide supporting evidence for tax incentive policies, such as allowing extra deductible entertainment expenses, in order to promote the use of CPA tax return attestation. On the other hand, Wang et al. (1993), and several tax officials in various national tax administration offices, indicated that the audit probabilities were the same for CPA attested returns and ordinary returns. Therefore, the empirical results also indicate that reinforcing the tax audit of ordinary returns may uncover more tax evasion, and enhance tax equity.

The coefficient of PAY is significantly greater than zero, and the marginal effect is NT\$131,964, implying that firms with tax balances due at filing time evaded more tax than those firms with tax refunds due. This finding demonstrates that, similar to the evidence documented by Chang and Schultz (1990) in the case of US individual income taxes, the prospect theory (Kahneman and Tversky, 1979) is applicable to the reporting of Taiwan's business income tax.

The coefficient of ETR is also significantly greater than zero. If a firm's effective tax rate increases by $1 \%$, its tax evasion increases by about NT $\$ 524$, as suggested by the fourth column of Table 5. This finding runs parallel to the Clotfelter (1983) study in which the individual income tax rate was found to be positively associated with under-reported income in the US. The CPAs interviewed in Chu (1988) also claimed, similarly, that a high rate of income tax was one of the main causes of tax evasion in Taiwan.

As the proxy of the dispersion of ownership, ORG is the only variable whose coefficient is not statistically significant. Although this result does not support the hypothesis that firms with dispersed ownership have less motivation to evade tax, it is 
worth reiterating that ORG may be an imperfect proxy of the dispersion of ownership, as stated earlier.

The coefficient of RANK is significantly positive, with the marginal effect being NT\$8,311. This implies that if the rank of one firm's net sales is one percentage point higher than another, then its tax evasion will be about NT $\$ 8,300$ higher. This finding supports the earlier proposition that a firm with a larger RANK has a higher probability of selection for audit by the tax office-in-charge, and that the tax office will scrutinize its tax returns more closely. The finding is also consistent with the argument of the political cost hypothesis in Zimmerman (1983).

Table 5 Tobit analysis of business income tax evasion

\begin{tabular}{lrrrrc}
\hline \multicolumn{1}{c}{ Variable } & Coefficient & $t$-statistic & $\frac{\partial \mathrm{E}(y \mid \bar{x})}{\partial x}$ & $\mathrm{E}(y \mid \bar{x})$ & $\overline{\mathrm{x}}$ \\
\hline CPAD & $-401,700$ & $-49.12^{* * *}$ & $-110,081$ & & 0.4099 \\
PAY & 530,570 & $54.84^{* *}$ & 131,964 & & 0.6563 \\
ETR & 178,950 & $8.84^{* *}$ & 52,448 & & 0.1666 \\
ORG & $-8,853$ & -1.23 & $-2,594$ & & 0.4857 \\
RANK & 28,356 & $17.92^{* *}$ & 8,311 & & 92.4698 \\
QUIC & $-12,817$ & $-6.56^{* *}$ & $-3,757$ & & -0.4560 \\
DEBT & $-5,660$ & $-2.59^{* *}$ & $-1,659$ & & -1.0181 \\
IRS1 & $-3,051,400$ & $-21.50^{* *}$ & & 106,812 & 0.3443 \\
IRS2 & $-3,106,800$ & $-20.79^{* *}$ & & 89,809 & 0.0650 \\
IRS3 & $-3,119,000$ & $-21.11^{* *}$ & & 86,351 & 0.2631 \\
IRS4 & $-3,170,700$ & $-21.37^{* *}$ & & 72,790 & 0.2008 \\
IRS5 & $-3,064,700$ & $-20.74^{* *}$ & & 102,533 & 0.1269 \\
IND1 & $-236,710$ & $-6.69^{* *}$ & & 42,683 & 0.0113 \\
IND3 & 88,796 & $7.41^{* *}$ & & 126,689 & 0.3618 \\
IND4 & $-73,888$ & $-8.68^{* *}$ & & 76,242 & 0.0934 \\
IND5 & $-42,058$ & $-2.41^{* *}$ & & 84,670 & 0.4222 \\
IND6 & 204,400 & $11.40^{* *}$ & & 174,485 & 0.0399 \\
IND7 & 99,041 & $4.55^{* *}$ & & 130,508 & 0.0299 \\
\hline Note5: & & & &
\end{tabular}

Notes:

1. $*: \mathrm{P}<0.05, \quad * *: \mathrm{P}<0.01$ (one-tailed test).

2. $\log$-likelihood $=-217,751, \mathrm{n}=34,356, \sigma=499,460$ (see Greene, (1995), at p.587).

Standing for a firm's financial strength, as expected, QUIC (quick ratio) is found to be negatively associated with tax evasion. However, DEBT (debt ratio) is somewhat unexpectedly, also negatively associated with tax evasion. This contradicts the prediction that a firm with high debt ratio has a lower tax paying ability, and thus a higher propensity towards tax evasion. This study made an effort to delete the outliers, i.e., 
observations with DEBT less than ln (1/1000), but the regression results are still similar to those in Table 5. A possible explanation for the negative relationship between DEBT and tax evasion is as follows; other things being equal, a high leveraged firm has a higher interest expense, thus lowering its taxable income and tax liability. Since its tax liability is already low (or is zero due to interest expense exceeding operation income), there is less motivation to evade tax.

Likelihood ratio tests have been employed in this study to investigate whether the jurisdiction dummies, IRS1, IRS2, ... IRS5, or the industry dummies, IND1, IND3, ..., IND7, or indeed both, can be discarded from the model specification. However, the test results all suggest that both jurisdiction and industry dummies have to be specified in the Tobit model. Furthermore, since the coefficients of all the jurisdiction dummies are quite close to one another, this study has attempted to impose the equality restriction on the coefficients (Greene 1995:134-136). The likelihood ratio test also rejects the equality constraint.

Although the $\beta$ coefficients of the jurisdiction dummies are all negative, the expected tax evasion $\mathrm{E}(y \mid x)$ within each jurisdiction is consistently positive. This is because $\mathrm{E}(y \mid x)$ has two components in equation (5); its first term $\beta^{\prime}{ }_{X} \Phi(z)$, which may be negative due to negative $\beta$ coefficients, is less than the second term $\sigma \phi(z)$, which is positive, in magnitude. Among the five tax jurisdictions, firms under the National Tax Administration of Taipei have the largest average tax evasion, followed by firms under the National Tax Administration of Southern Taiwan Province. A possible explanation to this finding is that firms in these two areas are more inclined to evade tax, but an alternative is that these two tax offices have better trained tax officials and thus have better audit performance. It would be a worthwhile study for tax analysts and policy-makers to further explore the relationship between the training of tax officials and the performance of tax offices. As indicated in Chen (1987), under-reported income varies significantly among different industries; column five of Table 5 also demonstrates that tax evasion varies with different industries.

\section{CONCLUSIONS}

The basic contribution of this paper is to provide empirical evidence supporting the proposition that CPA attested business income tax returns evade less tax than ordinary returns. This finding indicates that a CPA's tax attestation services can help firms to fulfill their tax obligations, and that this supports the use of tax policies offering incentives. On the other hand, the empirical results of this study also imply that a transfer of some of the effort from the auditing of CPA attested returns, towards the scrutiny of ordinary returns, may uncover more tax evasion, and thus enhance overall tax equity.

Turning to the administrative policy on tax return filing, this study suggests that the scope of CPA attested tax returns should be extended to include more firms. According to the 'Measures Governing the CPA Tax Returns Attestation Entrusted by Profit-seeking Enterprises' prescribed by the Ministry of Finance in 1982, a firm with net sales of NT $\$ 100$ million or more, should entrust a CPA to attest its tax return. Since the mid-1980s, the pass rates of CPA examinations have been significantly higher than in the preceding period, indicating therefore, that there are currently sufficient CPAs to match 
any demand growth. Thus, it seems that an extension of the scope of tax attestation, for example, a lowering of the standard from NT\$100 million to NT\$80 million, would be feasible. In order to punish those firms who willfully disregard the attestation requirement, the Legislative Yuan should add a specific article to the Income Tax Law delegating to the Ministry of Finance the power to penalize these firms.

In 1991, the Taiwanese government narrowed the scope of the Expanded Paper Review (EPR) system from firms with total receipts not exceeding NT $\$ 40$ million to the current standard of NT $\$ 30$ million. As described in the Introduction to this study, the EPR system helps to reduce the cost to the government of auditing small and medium enterprises (SMEs), and these SMEs can avoid tax audits on detailed accounting records and documentary evidence. However, the EPR system conflicts with the policy of fostering the SMEs' establishment of sound accounting systems and of maintaining honest accounting records. This study also recommends, therefore, that tax policy-makers should narrow the scope of the EPR system further by lowering the upper limit, for example, from NT\$30 million to NT\$25 million or even NT\$20 million. This may also have a knock-on effect of increasing the use of CPA tax attestation.

For firms using CPA attested tax returns, their CPA can represent them in dealings with tax authorities, thus saving their time and avoiding any psychological anxiety caused by dealing with tax officials. On top of this, the empirical results of this paper indicate that 'the assessed additional tax after audit' (the tax evasion defined in this paper) is lower for CPA attested returns than for ordinary returns, by an average of NT $\$ 110,000$, suggesting that those firms not currently engaging a CPA to attest their tax returns should re-evaluate their filing strategy. However, in addition to these benefits, consideration should also be given to issues such as CPA fees, as well as the cost and benefits coming from a CPA's reconstruction of a client firm's accounting system. These issues should be taken into consideration as a whole by firms reviewing the alternative of using CPA tax attestation.

Some research limitations should be noted. As this paper aims to contrast the tax evasion of CPA attested returns with that of ordinary returns, the costs of CPA fees, which must be set against the savings of a firm's labor and time for tax return filing, are issues that are not investigated in this paper. Due to the lack of relevant data in the tax returns, it seems that an exploration of this aspect of tax filing can only be accomplished by a survey study. Furthermore, the details contained in the tax return data file compiled by the Data Processing Center represent the numbers adjusted to meet the tax law provisions by the firm, or by its CPA, not the original numbers recorded for the firm's financial accounting purposes. Therefore, this paper cannot effectively investigate how firms manipulate their income, through the selection of appropriate accounting principles, in order to pay less tax.

In 1998, Taiwan adopted an imputation credit system, the 'two taxes into one' system, in order to integrate business and individual income taxes. In accordance with the current Article 66-9, which took effect in 1998, a firm's post-tax earnings incur 10\% surtax if not distributed. However, if a CPA attested tax return was assessed to have under-reported taxable income, the same Article also prescribes that the $10 \%$ surtax which should have been levied on the additional undistributed earnings will be exempted. Although this is a new tax incentive aimed at encouraging the use of CPA attested tax 
returns, it appears that more research is needed to explore whether this provision is reasonable, particularly with regard to the issue of whether this provision will encourage unscrupulous CPAs to help their clients to evade the surtax.

(Submitted July 1998; accepted March 1999.)

\section{REFERENCES}

Allingham, M.G. and A. Sandmo. 1972. Income tax evasion: A theoretical analysis. Journal of Public Economics 1 (November): 323-338.

Amemiya, T. 1984. Tobit models: A survey. Journal of Econometrics 24 (January/February): 3-63.

Beck, P.J., J.S. Davis and W. Jung. 1991. Experimental evidence on taxpayer reporting under uncertainty. The Accounting Review 66 (July): 535-558.

Broman, A.J. 1989. Statutory tax rate reform and charitable contributions: Evidence from a recent period of reform. The Journal of the American Taxation Association 11 (Fall): 7-21.

Chang, O.H. and J.J. Schultz Jr. 1990. The income tax withholding phenomenon: Evidence from TCMP data. The Journal of the American Taxation Association 12 (Fall): 88-93.

Chen, Li-wen. 1987. Imputation of the tax evasion of business income tax from Taiwan's underground economic activities. Masters thesis, Graduate Institute of Public Finance, National Chengchi University, (in Chinese).

Chu, C.Y. Cyrus. 1988. Causes and indicators of business income tax evasion in Taiwan-An application of the MIMIC model. Taiwan Economic Review 16 (December) (in Chinese): 481-489.

Clotfelter, C.T. 1983. Tax evasion and tax rates: An analysis of individual returns. The Review of Economics and Statistics 65 (August): 363-373.

Erard, B. 1993. Taxation with representation: An analysis of the role of tax practitioners in tax compliance. Journal of Public Economics 52 (September): 163-197.

Goldberger, A.S. 1964. Econometric Theory. New York: Wiley.

Greene, W.H. 1995. Limdep Version 7.0 User's Manual. New York: Econometric Software, Inc. 2000. Econometric Analysis. 4th ed. New York: Macmillan.

, and A.O. Quester. 1982. Divorce risk and wives' labor supply behavior. Social Science Quarterly 63 (March): 16-27.

Huang, Yophy. 1982. An empirical study on the tax evasion of Taiwan's individual income tax. Masters thesis, Graduate Institute of Public Finance, National Chengchi University, (in Chinese).

Judge, G.G., W.E. Griffiths, R.C. Hill, H. Lütkepohl, and T. Lee. 1985. The Theory and Practice of Econometrics. New York: Wiley.

Kahneman, D. and A. Tversky. 1979. Prospect theory: An analysis of decision under risk. Econometrica 47 (March): 263-291.

Klepper, S., M. Mazur, and D. Nagin. 1991. Expert intermediaries and legal compliance: The case of tax preparers. Journal of Law and Economics 34 (April): 205-299.

Lin, Hui-lin. 1997. Specification and selection of econometric models for censored dependent variable-The application of an R\&D model. Taiwan Economic Review 25 
(March), (in Chinese): 73-94.

Maddala, G.S. 1983. Limit-Dependent and Qualitative Variables in Econometrics. New York: Cambridge University Press.

Spilker, B.C., R.G. Worsham Jr., and D.F. Prawitt. 1999. Tax professionals' interpretations of ambiguity in compliance and planning decision contexts. The Journal of American Taxation Association 21 (Fall): 75-89.

Tobin, J. 1958. Estimation of relationships for limited dependent variables. Econometrica 26 (January): 24-36.

Wang, Yi-hsin., Chu-pei Lee, Hrong-tai Fai, Shiou-chih Wang and Guey-song Hwang. 1993. The benefit of using CPA attested tax return research. Report of the Department of Accounting, National Chung Hsing University (National Taipei University), (in Chinese).

Yaniv, G., 1999. Tax compliance and advance tax payments: A prospect theory analysis. National Tax Journal 52 (December): 753-766.

Zimmerman, J.L. 1983. Taxes and firm size. Journal of Accounting and Economics 5 (August): 119-149. 


\title{
會計師稅務簽證與租稅逃漏
}

\begin{abstract}
林世銘
國立臺灣大學會計系副教授

摘要：為協助營利事業履行納稅義務並減輕稅捐稽徵機關之工作負荷, 我國 所得稅法第一百零二條規定營利事業得委託會計師辦理結算申報與稅務行政 救濟等事項。對於委託會計師辦理稅務簽證申報之營利事業, 所得稅法並給 予盈虧互抵、得列支較高之交際費、較晚之延長申報期限等租稅獎勵措施。 惟截至目前為止, 尚缺乏證據顯示給予會計師稅務簽證租稅優惠是否為稅務 行政上應該採行的必要措施。對於會計師税務簽證申報案件, 應加強稅務查 核或應減輕查核並予以擴大採用, 也尚無足夠的證據作為制訂租稅政策的參 考。本文之研究目的即在於利用我國各企業之營利事業所得稅申報資料與税 捐機關之稅額核定資料, 比較會計師稅務簽證與普通申報案件之租稅逃漏情 況, 觀察會計師稅務簽證制度是否確可幫助企業履行納稅義務, 從而達成减 輕稅捐機關工作負荷之目標, 以作為評估會計師秷務簽證之效益的實證證據。

原則上, 政府僅對部份大型企業以法令強制其採行會計師稅務簽證, 其 餘企業均可自由選擇採用會計師稅務簽證申報而享受各種租稅優惠。但以民 國八十三年為例, 採用會計師稅務簽證之企業僅占全體申報家數之 $8.2 \%$, 尚 不及一成（詳英文版表 1)。財政部依據所得稅法授權訂定之「營利事業委託 稅務代理人查核簽證申報辦法」強制規定金融保險業、上市公司、以及全年 營業額在一億元以上之營利事業, 應採用會計師税務簽證申報, 但是應採用 會計師稅務簽證而未採用者, 目前並無相關處罰規定。因此, 在稅務人力不 足或查核技術無法面面俱到的情况下, 不願按照會計師簽證稅額申報之企 業, 極有可能違法採用普通申報而僥倖逃漏稅負 (詳英文版註 1)。實際上, 會 計師稅務簽證未被企業普遍採用之另一重大原因為全年營業收入淨額及非營 業收入（不包括土地之附著物的交易增益暨依法免稅之收入）合計在新台幣 三千萬元以下之營利事業, 尚得選擇「擴大書面審核制度」, 不管其實際淨利 或淨損失之多葟, 若申報之純益率在各該年度擴大書面審核實施要點所規定 之各行業純益率標準以上並繳清稅款者, 轄區國稅局僅就其申報之書面資料 予以核定稅額, 原則上免再調帳查核。擴大書面審核制度可以節省政府之稽 徵成本, 避免浪費查核人力於金額較小之案件; 但因稅捐機關只就申報書予 以核定稅額, 反而不能鼓勵中小企業誠實記帳與建立健全之會計制度。部份 確有雐損之企業, 可能為避免設帳或調帳查核之麻煩, 寧願依規定之純益率 標準申報納稅; 而漏開鉅額發票之企業, 也可能因擴大書面審核制度只繳納 少數稅款即可蒙混過關。
\end{abstract}


因此, 若能將各種可能影響企業逃漏税之因素納入計量分析模型, 提出 證據證明經會計師稅務簽證之案件, 較無租稅逃漏之情形, 確有助於降低稅 捐機關之查核負荷, 則值得政府研議將會計師稅務簽證之強制適用範圍, 自 營業額一億元以上予以適度降低; 並且將擴大書面審核制度之適用範圍自全 年收入三千萬元以下予以進一步縮小。行政部門或立法委員也應考慮提案, 對未依規定採用會計師稅務簽證之營利事業, 明文制定相關罰則。本文之研 究證據, 應可供為制定上述租稅政策之參考。本文英文版除於第一節說明研 究背景與研究目的外, 在第二節經由國內外與租稅逃漏、會計師稅務簽證有 關文獻之探討, 說明以往研究之成果與其對本研究之影響和關連。所探討之 主要文獻包括 Allingham and Sandmo (1972)、Clotfelter(1983)、Chang and Schultz (1990)、Beck et al.(1991)、Klepper et al. (1991)、Erard (1993)、 Spilker (1999)、Yaniv (1999)、黄耀輝（1982）、陳麗玟（1987）、朱敬一 (1988)、王怡心等(1993)各文。

財政部財稅資料中心歷年來皆將各營利事業所得稅結算申報書的「損益 及稅額計算表」與「資產負債表」以及經稅捐機關審查後之「核定」損益及 稅額計算表的每一會計科目餘額予以登錄, 並利用電腦磁碟或磁带加以儲 存。本文即利用財稅資料中心最近提供之民國八十三年度全體營利事業的上 述三種申報損益表檔、申報資產負債表檔、核定損益表檔之電腦磁带資料, 自其中選取樣本, 分析稅務簽證案件與普通申報案件之租稅逃漏情況與其解 釋變數 (八十三年度之營利事業所得稅在八十四年申報後, 稅捐機關尚須經 一年以上的時間加以審查核定, 才能將各項申報與核定金額登錄於磁碟中, 八十三年度之資料是財税資料中心在八十七年二月以前所能提供之最新資 料)。因為全年收入在三千萬元以下之營利事業, 可適用擴大書面審核之申報 制度; 且「營利事業委託稅務代理人查核簽證申報辦法」規定全年營業額在 一億元以上之營利事業, 應採用税務簽證申報, 因此本文之研究對象為全年 收入在三千萬元至一億元之營利事業, 觀察其使用稅務簽證與否和租稅逃漏 之關連, 以使稅務簽證案件與非簽證（普通申報）案件之樣本組成來源較為 公平合理。民國八十三年度之申報家數與申報類別、樣本之篩選過程與組成 家數, 請分別參見英文版表 1 及表 2 。

本文將逃漏稅額 $(\mathrm{Y})$ 定義為經稅捐機關查帳核定後所增加的稅額, 亦即 依核定課稅所得額計算之所得稅, 減去企業申報課稅所得額之所得稅負。雖 然 Allingham and Sandmo (1972) 與 Clotfelter (1983) 皆以短漏報之所得 ( underreported income) 作為租稅逃漏 (tax noncompliance) 之代理變數, 但是本文利用查帳核定後增加之稅額 (assessed additional tax) 作為租稅逃 漏之指標, 原因在於使用漏稅金額較能直接說明各個解釋變數對稅收的影 響。此外, 本文所定義之租稅逃漏並未包括沒有被查獲的未申報所得（例如 
毒品交易所得), 以及已申報但短報收入或虛報費用而未被國稅局查獲的逃漏 情形。因為研究樣本中有 19,904 家企業（約佔樣本 58\%) 並未逃漏稅額, 因此本研究之依變數有極重大的比例聚集於 0 , 經濟學家稱此種偏態資料為 設限資料 (censored data)。本文利用 Tobit 模型作為分析設限資料之主要計 量工具, 對於 Tobit 模型之應用, 尤其是如何對虛擬變數加以分析解釋, 英 文版有詳盡之說明。

英文版表 5 為本文利用 Tobit 最大概似法估計租稅逃漏之結果(該表中之 所有解釋變數的定義說明於英文版), 諸解釋變數中, 虛擬變數 CPAD之係數 將用來檢定稅務簽證與普通申報之逃漏情況是否相同。誠如第二節文獻回顧 所述, 至今似無完整之經濟分析模型足以預測稅務簽證對企業租稅逃漏的影 響, 本文只能嘗試以實證結果說明兩者之關連。表 5 顯示 CPAD 之 $\beta$ 係數在 $\alpha=0.01$ 之水準下, 顯著小於 0 , 而邊際影響為-110,081, 表示除了 CPAD 變數以外, 若各解釋變數皆取樣本平均數作為比較基準點, 則採用會計師税 務簽證申報的案件, 平均比普通申報案件少逃漏租稅約 11 萬元。因此, 本文 之實證結果支持我國所得稅法給予稅務簽證案件較長之延期申報期限、較高 之交際費等租稅優惠。另一方面, 因為王怡心等(1993)之研究指出稅捐機關 抽查稅務簽證公司之比率, 並未低於未委託簽證之公司; 且據數位不同轄區 之國稅局官員指出, 在電腦選案查核方面, 會計師稅務簽證案件與普通申報 案件係一併交由電腦選案抽查, 並未事先設定不同之選案率; 因此本文之實 證結果也顯示加強查核普通申報案件, 可發掘較高的逃漏稅額, 對促進租稅 公平將有正面之效果。

表 5 中 PAY之係數顯著大於 0 , 且邊際影響值為 131,964, 顯示暫繳與 被扣繳不足而結算申報時尚須補稅之企業, 比不必補稅之企業, 平均多逃漏 租稅約 13 萬元。這個證據顯示展望理論 (prospect theory) 也適用於我國的 營利事業所得稅之申報情況。

有效稅率 ETR 之係數也顯著大於 0 , 由第四欄之數字顯示, 若有效稅率 增加 $1 \%$, 則企業之逃漏稅額平均約增加 524 元。這一個研究發現與 Clotfelter(1983)美國個人所得稅率上升則逃漏報所得增加之實證結果相似, 也與黄耀輝(1982)所得級距愈高, 逃漏稅負比率愈高的研究發現相近。接受 朱敬一(1988)訪談的會計師也認為稅率過高是造成逃漏稅的主因之一。

ORG之 $\beta$ 係數是唯一未顯著異於 0 者, 雖然這個結果未能符合本文 $「$ 所 有權愈分散, 企業逃漏稅的利益愈不能由少數人 (特別是管理當局) 所獨享, 因此逃漏程度愈低」的預期(因為所有權愈分散, 企業逃漏稅的利益愈不能由 少數人所獨享), 但是這或許是本文未能使用更佳的代理變數的結果。因為所 得稅申報書中並無董監事或企業經理人的持股比率資料, 本文僅能以 ORG 
（是否為股份有限公司）作為所有權分散程度的代理變數。

RANK 之係數顯著大於 0 , 且其邊際影響為 8,311, 顯示企業在各區國 稅局之營業淨額的排行, 每上升一個百分點, 則逃漏稅之金額平均約增加 8,300 元。這個數據支持本文「企業 RANK 愈大, 被轄區國稅局查帳的程度 愈仔細」之推測。Zimmerman (1983) 的政治成本假說（political cost hypothesis) 也在本文的研究範圍内, 獲得支持的證據。

本文原本預測速動比率 QUIC 愈高, 則逃漏情況愈低; 負債比率 DEBT 愈高, 逃漏情況愈多。但是在表 5 的實證結果中, QUIC 與預期的結果雖然 相同, DEBT 的結果卻與預期相反, 即負債比率愈高者逃漏的情況反而愈少。 本文曾嘗試捨棄負債比率的 outliers (異常值), 即捨去小於 $\ln (1 / 1000)$ 之觀 察值, 但是結果仍與表 5 相似。從另一個角度來看, DEBT 之係數為負的可能 原因在於負債比率愈高的公司, 利息費用愈高, 所得愈低, 以致於稅負愈小, 愈不需要逃漏稅。另一種可能原因是虧損的公司舉債愈多, 而虧損的公司不 必繳納所得稅, 當然無逃漏稅之必要。

對於國税局轄區之虛擬變數 IRS1, ‥,IRS5，與行業別之虛擬變數 IND1,IND3, ‥,IND7 等, 本文曾利用 likelihood ratio test 測試這些變數是否

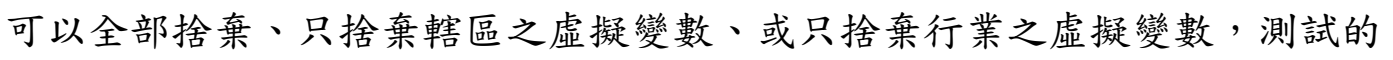
結果都顯示本研究必須同時使用這些轄區與行業變數。鑑於各轄區虛擬變數 之係數皆極為相近, 本文也曾在 Tobit 模型中強制使 IRS1, ‥,IRS5 之係數都 相等 (impose equality restriction, Greene 1995, pp.134-136)，但是 likelihood ratio test 仍然拒絕了係數都相等的假設。分析轄區對租稅逃漏的影 響時, 本文係使用第(5)式計算各轄區按其他變數平均值 (但其他轄區之虚擬 變數皆為 0) 作為樣本點的逃漏金額, 結果發現台北市國稅局轄區之平均逃 漏稅額 106,812 為最高, 南區國稅局次之。可能的原因之一是位於此二轄區 之企業有較高的逃漏傾向; 另一個可能原因則是這兩個國稅局的查核人員能 力較佳、查帳效果較好, 這個現象值得未來研究者與政府有關單位就各國稅 局之人力配備、教育程度等再予深入探究。

本文之實證結果提供稅務簽證案件比普通申報案件較無租稅逃漏之證 據。此一研究發現, 說明會計師所提供之稅務簽證服務, 確可協助企業履行 納税義務, 因此對於應否繼續給予稅務簽證租稅優惠或給予更多的獎勵措 施, 本研究提供了支持的有利證據。另一方面, 未經簽證之普通申報案件, 經查帳後所補繳之稅額, 比稅務簽證案件平均多出約 11 萬元, 而依王怡心等 (1993)之研究以及稅務官員指出稅捐機關抽查稅務簽證公司之比率, 並未低 於未委託簽證之公司, 因此未來稅捐稽徵機關似宜加強對普通申報案件之查 核, 且減輕稅務簽證案件之審查人力。 
在結算申報的稅務行政上, 本文之研究結果也支持進一步擴大會計師稅 務簽證之適用範圍。政府曾於民國八十年將擴大書面審核制度的適用範圍, 自全年收入四千萬元以下縮小為三千萬元以下，因為近年來放寬會計師考試 之錄取率, 目前政府應可考慮配合會計師人力之供給增加, 進一步縮小擴大 書面審核制度的適用範圍, 鼓厲企業採用稅務簽證, 以確實做到核實課稅促 進租税公平。對於民國七十一年發布之「營利事業委託稅務代理人查核簽證 申報辦法」, 政府亦應考量修正擴大稅務簽證之強制適用範圍, 並研擬增修法 律, 對未依規定採用稅務簽證之企業予以適當的處罰。

就企業而言，採用稅務簽證可由會計師出面應付稅務官員之審查工作， 減輕企業人力成本以及被查稅所带來的精神上之不安或煩躁; 再加上本文發 現稅務簽證被補税的機會與平均金額都小於普通申報案件, 因此尚未採用税 務簽證的企業, 似乎應重新進行選擇報稅方式的決策。進行決策時, 固應參 考會計師公會所訂定的稅務簽證收取酬金標準, 更應考量企業改善會計制度 的增支成本與效益。

本文受限於研究資料, 僅針對租稅逃漏之情况, 探討會計師進行稅務簽 證之效益, 而未能研究稅務簽證對促進企業健全會計制度带給企業與社會之 效益; 對於企業採用秷務簽證所花費之成本以及節省企業人力物力之效益, 本文亦未進行有關之分析, 未來之研究似可採用問卷調查等適當之方法繼續 予以探討。

我國自民國八十七年起採行兩税合一，新修正之所得稅法第六十六條之 九規定在計算保留盈餘加徵 10\%稅負之稅基時, 對於稅務簽證案件應以申報 的課稅所得額作為計算之起點, 換言之, 如果稅捐機關核定之課稅所得額增 加, 則調增的部分免被加徵保留盈餘的 $10 \%$ 稅負。此乃新稅制賦予稅務簽證 的新獎厲措施, 虽然符合本文支持獎勵稅務簽證的研究發現, 但是這樣的獎 勵措施是否公平合理、是否反而助長不肖會計師以稅務签證幫助企業逃漏保 留盈餘的稅負, 也值得未來深入探究。

關鍵字：稅務簽證、租稅逃漏、會計師、Tobit 模型、租稅政策。 